This is an electronic reprint of the original article. This reprint may differ from the original in pagination and typographic detail.

Author(s): Karjaluoto, Heikki; Mustonen, Nora; Ulkuniemi, Pauliina

Title: $\quad$ The role of digital channels in industrial marketing communications

Year: $\quad 2015$

Version:

Please cite the original version:

Karjaluoto, H., Mustonen, N., \& Ulkuniemi, P. (2015). The role of digital channels in industrial marketing communications. Journal of Business and Industrial Marketing, 30(6), 703-710. https://doi.org/10.1108/JBIM-04-2013-0092

All material supplied via JYX is protected by copyright and other intellectual property rights, and duplication or sale of all or part of any of the repository collections is not permitted, except that material may be duplicated by you for your research use or educational purposes in electronic or print form. You must obtain permission for any other use. Electronic or print copies may not be offered, whether for sale or otherwise to anyone who is not an authorised user. 


\title{
The role of digital channels in industrial marketing communications
}

\author{
Heikki Karjaluoto ${ }^{1}$ \\ Nora Mustonen ${ }^{2}$ \\ Pauliina Ulkuniemi ${ }^{3}$ \\ ${ }^{1}$ Corresponding author \\ Professor of Marketing \\ School of Business and Economics \\ University of Jyväskylä \\ PO Box 35 \\ FIN-40014 University of Jyväskylä, Finland \\ Tel. +358 (0)40576 7814 \\ Fax. +358 (0)142602021 \\ E-mail: heikki.karjaluoto@jyu.fi \\ ${ }^{2} \mathrm{PhD}$ Candidate \\ School of Business and Economics \\ University of Jyväskylä \\ PO Box 35 \\ FIN-40014 University of Jyväskylä, Finland \\ Tel. +358 (44) 5774449 \\ Fax. +358 (0)142602021 \\ E-mail: nora.mustonen@jyu.fi \\ ${ }^{3}$ Professor of Marketing \\ Oulu Business School \\ University of Oulu \\ PO Box 4600 \\ FIN-90014 University of Oulu, Finland \\ Tel. +3580294482980 \\ Fax. +358 (8) 5532906 \\ E-mail: pauliina.ulkuniemi@oulu.fi
}

\section{Author bios}

Heikki Karjaluoto is a Professor of Marketing at the University of Jyväskylä, Finland.

His research interests include marketing communications, electronic business, and customer value. Previous publications have appeared in the European Journal of Marketing, Electronic Markets, Journal of Business \& Industrial Marketing, Journal of Economy Psychology, Telecommunications Policy, among others. 
Nora Mustonen is a $\mathrm{PhD}$ candidate in the marketing program at Jyväskylä University School of Business and Economics. Her research interests include environmental values and marketing communications in business-to-business marketing. She also majors in psychology.

Pauliina Ulkuniemi is a Professor of Marketing at the University of Oulu, Finland. Her research interests lie in value creation in business relationships in different industry contexts. She has published in the International Journal of Service Industry Management, Scandinavian Journal of Management, Journal of Business \& Industrial Marketing, and Industrial Marketing Management among others. 


\title{
The role of digital channels in industrial marketing communications
}

Heikki Karjaluoto, Nora Mustonen, \& Pauliina Ulkuniemi

\begin{abstract}
Purpose - The purpose of this research is to investigate industrial marketing communications tools and the role of digital channels. The research draws from the literature on industrial marketing communications to examine its goals and intended utilization in industrial firms.

Design/methodology/approach - An empirical multiple case study conducted among six industrial firms examines the current state of digital marketing communications (DMC).

Findings - The study gleans three research insights. First, although DMC is one of the most important industrial marketing communication tools, firms have not yet used it to its full potential. Second, firms use DMC to enhance customer relationship communications, support sales, and create awareness. Third, firms have not employed social media tools as a part of DMC as widely as traditional digital tools.
\end{abstract}

Research implications - Although the findings mirror those in DMC literature in general and industrial marketing communications in particular, they put more emphasis on the role of DMC in customer relationship communications and sales support.

Practical implications - DMC provides an opportunity to deliver various marketing objectives, such as creating brand awareness, increasing and supporting sales, and improving communication with existing customers. Different DMC tools are required for each of these objectives.

Originality/value - This study is among the first to examine the rapidly changing communications landscape and the spread of digital channels in industrial marketing communications.

Keywords Digital marketing communications, industrial marketing communications, tools, case study, branding, social media

Article classification Research paper 
In general, industrial companies are not at the forefront of adopting new instruments and channels for marketing communications. However, the growing number of stakeholders and the fragmentation of the media landscape have led to a rethinking of marketing communications in industrial firms. Digital marketing communications (DMC), particularly when linked to corporate branding and in support of personal selling, has begun attracting the interests of both practitioners and academics (Deeter-Schmelz \& Kennedy, 2002; Foster, 2005; Järvinen et al., 2012; Michaelidou et al., 2011). For example, research has recently examined ways to combine DMC with traditional marketing communications to communicate with industrial customers (Foster, 2005; Michaelidou et al., 2013), likely because traditional marketing communications (e.g., industrial advertising) play a lesser role than customer relationship management, personal interaction, and other variables in the industrial marketing mix-namely, product, price, and place (Foster, 2006; Gilliland \& Johnston, 1997; Jackson et al., 1985). Every company faces the question of how to maximize the potential gains from digital media channels. As a result, effective marketing communication has become a strategic management objective for successful firms (Cornelissen, 2004).

Not only have marketing communication channels changed, but so too have the ways industrial firms communicate with their customers. Over time, a power shift has occurred from organizations to customers (Hennig-Thurau et al., 2010; Weber, 2009). Information sharing on the Internet has allowed everyone to express an opinion, which in turn has led people to trust peers more than organizations (Greenberg, 2010a, 2010b). This change has created several new challenges for marketers. Companies now acknowledge the need to listen to their customers more, engage them in conversation, be transparent, and communicate with them openly and 
empathetically. The marketing specialist's role has evolved from being a broadcaster to being an aggregator who brings content together to enable collaboration and participation in communities. Marketing communications now includes creating online communities, generating leads from online environments, and collaborating with customers to gain a better understanding of their needs (Weber, 2009).

Several previous studies have identified issues meriting further research, such as how firms use digital communications channels and how use of these channels affects buyer-seller relationships (Constantinides \& Fountain, 2008; Day \& Bens 2005; Foster, 2005; Hennig-Thurau et al., 2010; Järvinen et al., 2012; Kerrigan \& Graham, 2010; Michaelidou et al., 2011; Mulhern, 2009; Parasuraman \& Zinkhan, 2002). Of particular interest is how industrial marketers combine online and offline marketing communication efforts to create more value for their customers and other stakeholders (Foster, 2005). The current study aims to extend this research by examining the role of digital channels in industrial marketing communication. More specifically, the goal of this study is to determine what actions industrial firms have taken to increase the use of digital elements in their marketing communications and what challenges DMC presents. Against this backdrop, we formulate three research questions: What are companies' objectives for DMC? To what extent do industrial companies adopt DMC? and What challenges does the implementation of DMC present for industrial marketing?

This study proceeds as follows: We first provide a review of extant literature to determine the characteristics of industrial marketing communications and DMC. We then deepen theoretical understanding with an empirical multiple case study. Finally, we discuss the implications of our findings, present the study limitations, and suggest avenues for further research. 


\section{DMC in industrial firms}

Personal communications tools, primarily the sales force, have been foremost in the business-tobusiness (B2B) communication mix (Lilien \& Weinstein, 1983). Other tools play a supportive role by creating synergies in achieving sales objectives (Rosenbloom, 2007; Singha \& Koshyb, 2011). In an industrial marketing setting, managing the various types of interactions is made more complex by the number of organizational levels and people involved in communication processes (e.g., Ford et al., 1998). With the rise of digital media, the coordination and integration of channels has become even more challenging, though more opportunities for better targeting and measurement have also emerged.

\section{DMC}

DMC refers to the use of new digital communication channels (or technologies/tools) to create an integrated, targeted, and measurable communication process that helps companies acquire and retain customers while building a deeper relationship with them (Mulhern, 2009). Other terms closely associated with DMC include "e-marketing", "Internet marketing", and "new media" (Hennig-Thurau et al., 2010). DMC has its roots in interactive marketing and one-to-one marketing (Wymbs, 2011) and, as a concept, is preferable to either e-marketing or Internet marketing, which are more limited in focus. DMC represents personalized and participatory media in which customers become contributors to content and creators of marketing communication, rather than just passive targets (Hennig-Thurau et al., 2010; Wertime \& Fenwick, 2008). Although DMC has its roots in consumer settings, the idea of engaging customers in a two-way, personalized dialogue is also relevant to industrial marketing. In this study, we use the term DMC to describe both digital media channels and strategies. 
Industrial firms are uncertain about which elements are essential to the digital marketing process and which digital strategy they should follow (Wertime \& Fenwick, 2008). Research highlights content and interactivity as the two main pillars of DMC (DuFrene et al., 2005; Godfrey et al., 2011; Srinivasan et al., 2002). Interactivity in marketing communications, or the degree to which two-way communication is facilitated through different customer-support or communications tools, is positively linked to loyalty in electronic environments (Srinivasan et al., 2002). In turn, managerial literature highlights the changing roles of the buyer and seller in terms of content creation, pointing out that marketers today must earn customer attention by publishing interesting, useful, and/or helpful content, for example, in the form of a blog (Halligan \& Shah, 2009; Scott, 2010).

\section{Objectives and tools of DMC in industrial firms}

Research on digital marketing in a B2B setting is scarce, though it is increasing. Both businessto-consumer (B2C) and B2B literature identify four main objectives of digital marketing: (1) it increases efficiency of communications (Sharma, 2002; Walters, 2008), (2) it fosters customer relationship communications and interaction (Berthon et al., 1998; Welling \& White, 2006), (3) it creates awareness and helps build brands (Drèze \& Hussherr, 2003; Järvinen et al., 2012; Manchanda et al., 2006; Mangold \& Faulds, 2009; Michaelidou et al., 2011; Weinberg \& Pehlivan, 2011; Welling \& White, 2006), and (4) it generates sales leads (Bodnar \& Cohen, 2012; Welling \& White, 2006). In addition, recent advances in communications technology, such as the rise of interactive media, have emphasized some of the more general objectives of marketing communications, especially interactivity and efficiency. Customers have become content creators and active participants in the communication process (Hennig-Thurau et al., 
2010). In the B2B context, recent studies have asserted that social media, as one part of DMC, should concentrate on lead generation by publishing interesting content with a clear call-toaction element (Bodnar \& Cohen, 2012).

Michaelidou et al. (2011) were among the first to investigate digital marketing objectives and tools in industrial use. They proposed that the majority of industrial firms regard the use of social media, especially social networking platforms, as irrelevant to their business. The main objectives of industrial firms when using social networking services are attracting new customers, cultivating relationships, and increasing awareness. According to a survey study, the main objectives of digital marketing are creating awareness, enhancing brand image, and acquiring new customers (Järvinen et al., 2012). Practitioners and consultants also share this view by arguing that social media is most useful for $\mathrm{B} 2 \mathrm{~B}$ companies in acquiring new customers (Bodnar \& Cohen, 2012).

\section{Method}

To identify the current state of practice of DMC in industrial marketing, we performed an empirical study that followed a multiple case-study design (Yin, 1994). As DMC in industrial firms is still an emerging issue, we chose a qualitative approach to gain understanding of the nature of the marketing communication processes and how the digital channels are intertwined. To better capture the variety of industrial marketing contexts, we used the multiple case-study approach. We did not make comparisons between different cases but rather examined them as an ensemble representing the diversity of industrial firms. The case companies operate internationally as providers of high-technology solutions for metal, paper, electronics, mining, and energy industries. They produce goods that are generally of strategic importance for their 
customers. Consequently, buying processes typically involve complex decision making and are time consuming for both the buyer and the seller because they mainly require personal interaction. Examining the role of DMC in such a context enables us to capture the specific challenges of industrial marketing.

Most of the case companies plan their marketing communications at headquarters. Because the size of the firm has obvious implications for marketing management, our intention was to select companies that would be large enough to represent the challenges of marketing communications on a global scale but also to include smaller companies with a moderate-size marketing function. Doing so would enable us to determine how companies employ DMC in different organizational contexts.

We collected data by means of personal interviews and workshops. We also used material from company documents, websites, meetings, and open discussions. Table I presents the six case companies and the data. The interviews focused on obtaining the respondents' views of the changing communications landscape, digital channels, and their impact on industrial business in general and their own business in particular. The workshops included a group assignment to analyze the current status and future directions of marketing communications, especially DMC. The interviewees and workshop participants were case company employees with primary responsibility for marketing communications and sales management.

Table I about here

Data analysis followed an abductive reasoning (Dubois \& Gadde, 2002). In analyzing the data, we used open thematization, consisting of a three-step process of data reduction, data display, and drawing/verification of conclusions (Miles \& Huberman, 1994). For data reduction, we used theoretical insights drawn from the literature-namely, issues such as communication 
media, characteristics of marketing communication functions, integrated marketing communications (IMC), DMC, communication in customer relationships, and sales supportand organized the data according to these concepts. To perform the data display, we synthesized our interpretations of the themes and submitted them to the case companies to review in workshops. Workshop data helped complement and revise the interpretations. As a result of the analysis, we identified the actions the analyzed firms have taken to increase the digital elements of their marketing communications and the objectives set for DMC in relation to marketing communications.

\section{Results}

\section{An overview of marketing communications in the case companies}

Table II collates the results of the workshops, summarizing the current state of the case companies' marketing communications, and outlines the areas identified as targets for development. The strengths, weaknesses, and opportunities are classified into two categories arising from the workshop material, representing general marketing communications themes and tools.

Table II about here

In general, the interviewees agreed that creating awareness and strengthening the brand are the two most important objectives of marketing communications. In addition, the empirical material highlights the role of the marketing function in industrial firms as providing support to the sales function:

To support sales is, of course, our top priority. Then building up and strengthening a brand are very important. And then, just raising awareness. (Case D, interview) 


\section{DMC in industrial companies}

The importance and usage of DMC in the case companies have increased in recent years. However, DMC is not yet considered vital, and its implementation is incomplete and not planned well. Although the case companies consider DMC an effective instrument with great potential, they have not found ways to fully exploit it as an integral part of their overall marketing communications strategy. Currently, DMC activities consist primarily of traditional marketing communication actions relocated to an electronic environment.

The empirical data reveal three important areas in which DMC is already employed, or in which it is hoped to exert a positive influence: (1) communication in customer relationships, (2) sales support, and (3) brand building (Figure 1). The companies themselves recognize that communication with existing customers should be improved, especially in longer-term relationships. The companies also wish to use digital channels to increase brand awareness among prospective customers and to track high-quality sales leads.

Figure 1 about here

\section{Communication in customer relationships}

The case companies use e-mail to distribute newsletters and customer magazines and to send invitations to seminars, trade shows, and other events. E-mail is also widely used in person-toperson communication. The perceived effectiveness of e-mail may be a consequence of its similarity to face-to-face interaction in terms of exchanging customer-specific content with the added option of contact whenever it is most convenient to both parties. 
In addition to our website, we do not do much else than distributing our newsletter to our existing customers. We have been discussing how to make the newsletter more personalized for our various audiences. (Case A, workshop)

Our e-mail newsletters are highly targeted and have achieved high reading rates. (Case B, workshop)

Five of the six case companies offer digital customer magazines, and their role is expected to grow as the use of new devices such as tablets (e.g., iPads) spreads. They also use digital communication channels and tools such as social media (including blogging), user communities (e.g., Facebook, LinkedIn, Twitter, extranets, intranets), and user-generated content to some extent.

The greatest opportunity identified in using social media is that business operations can be handled more effectively as communication with customers becomes faster and more easily tracked. Firms may save time and resources because they can move communications onto forums hosted on extranets, webcasts, and direct-feedback channels and discussion forums. However, the case companies agree that complex business relationships still benefit from traditional forms of communication, such as face-to-face meetings, telephone calls, and e-mail interaction.

What hinders the applicability of social media to industrial marketing communications the most is the norm of confidentiality in business relationships. Most of the case companies and their customers are listed on the stock exchange. They also rely heavily on their R\&D activity, meaning that discussing problems on an open forum or blog might jeopardize their competitive 
advantage. Supplier-buyer communication on public forums may also adversely affect the company's other customer relationships:

Who is talking with whom...? You can lose customers if A gets to know about B. This is $B 2 B$ reality ... like it or not. (Panel discussion of key informants)

\section{Sales support}

DMC has two separate applications in sales support. One is conducting external marketing communication via digital channels and gathering information on sales leads using digital tools. The other is using DMC in internal communications between the sales and marketing functions. Digital channels enable the systematic exchange of customer feedback and intelligence, which may be used to create more customer-driven sales materials that support marketing and sales objectives alike.

A good illustration of how digitization has enhanced sales support is the increasing use of multimedia such as videos, animations, and digitized presentation materials produced by the marketing communication function. Companies that have used multimedia rate it positively, stating that it helps the sales function illustrate and further simplify complex products and solutions.

The case companies also regard the integration of social media into sales as problematic. Marketing managers believe that it is difficult to reach the right decision makers through digital marketing and social media:

Access to social media sites, for instance, Facebook and YouTube, was long forbidden in our organization. So, that makes it quite difficult to evaluate how social media could support our sales. (Case B, interview) 
The message, especially toward the decision makers [from investors], is the most difficult thing. They are hard to target online, they don't read our customer magazine e-mailed to them.... These kinds of deals are made in the sauna. (Case D, interview)

In B2B marketing, we don't know how to utilize social media, and I myself haven't figured out the right ways to utilize it. The challenge is how to implement the good things from $B 2 C$ marketing into the $B 2 B$ world. (Case D, interview)

However, some of the case companies have managed to link their digital marketing actions to their sales activities. In these firms, digital marketing and social media are mainly used to generate leads for the salespeople, often by driving traffic from social media sites to the organization's own website. In addition, the empirical material indicates that more effort should be put into generating good-quality leads and calls for action (e.g., encouraging potential customers to leave their contact details and receive something valuable in return, such as free content).

We are especially interested in how to increase our website traffic and identify the most useful leads from the visitors. In generating the [website] traffic, we still have problems in optimizing our site for search engines. This has resulted in a situation in which quite a number of Google searches lead to our competitors' websites. (Case A, workshop)

\section{Building awareness through DMC}


The case companies commonly noted that increased awareness of the company or its brand is a desired outcome of DMC. This desire is linked to two marketing goals: (1) reaching more prospects to increase sales and (2) building the company's image among audiences other than prospects and customers. The case companies linked the presence in digital channels to direct support of sales, but the aim to build awareness or recognition may also serve more general brand-related goals set for marketing communications. So far, public relations activities in the case companies have yielded positive outcomes, but all the companies perceived the cost of participating in trade shows and events as high compared with the measurable results. DMC attracts industrial marketers because it is more cost-effective than other traditional communications tools.

A new generation of managers who are used to living in a virtual world and being on the web will soon enter [all areas of] the business. I believe they will utilize these tools in a different way than we are used to, and when they enter the business world, they will bring those tools with them. (Case D, interview)

In terms of social media channels, the data indicate that the companies could use blogging more effectively to create awareness. Only one of the case companies actively blogs and attempts to lead opinion by influencing the attitudes of its customers and prospects. One company representative recognized his company website among the sources cited for a Wikipedia entry. Some had also considered the idea of the company creating its own industryspecific reference work for publication. Company representatives also saw opportunities for less formal and more spontaneous communication with different audiences on the Internet: 
Blogs would enable fast marketing, which is interesting. In blogs, people share their own opinions, and it is more informal. This means that the marketing doesn't have to be so polished. (Case $\mathrm{D}$, interview)

On our website, the blog has been the main thing, and all the others, like Twitter and Facebook, are just supporting it. I opened them just because of the image goal. (Case E, interview)

However, the interviewees also expressed doubts about whether a blog really is useful in terms of content and effectiveness:

A blog is just a conversation platform, and I don't think it differs from an e-mail conversation. It is just a different physical media. Of course, more people can participate in blogs. (Case $\mathrm{C}$, interview)

Yes, we have a blog, but I must say that it is one of the worst channels. I am not convinced at all that there is any kind of benefit in it. Of course, it can be good if somebody has the time to write it, and if somebody has the time to read it. But I would argue that it is a very ineffective channel. (Case $\mathrm{C}$, interview)

\section{Discussion}

The objectives of the study were twofold. First, we examined which objectives industrial marketers have set for DMC. Second, we described the actions that industrial firms have taken to digitalize their marketing communications and the possible challenges DMC implementation 
presents. Our extensive empirical study reveals that industrial marketers hope to gain strategiclevel benefits from DMC, most importantly enhanced cost-effectiveness and competitive advantage that may arise from innovative ways of communication.

Successful utilization and development of DMC demands open-minded, innovative, and courageous marketers, but currently many such people seem scarce in industrial settings. As a result, industrial companies have added basic forms of DMC (a website, digital sales materials, and e-mail) to their marketing mix but still rely on the use of offline tools, mainly because of the preference for personal communication and the long-term nature and organizational complexity of business relationships.

\section{Implications for industrial marketing communications literature}

Three main goals set for DMC in industrial companies mirror those of DMC literature in general (Kerrigan \& Graham, 2010; Mangold \& Faulds, 2009; Mulhern, 2009; Weinberg \& Pehlivan, 2011; Welling \& White, 2006) and industrial marketing communications in particular (Foster, 2005; Järvinen et al., 2012; Michaelidou et al., 2011). These include (1) maintaining communication with existing customers, (2) providing support to the selling process, and (3) building general awareness among stakeholders. Of these three, our findings show that companies put the most emphasis on the role of DMC in customer relationship communications and sales support.

Extant literature argues that relationship selling and advances in communications technology are transforming industrial selling (Greenberg, 2010b; Järvinen et al., 2012; Michaelidou et al., 2011; Wotruba, 1996). The role of the customer is changing from one of passive recipient to one of content creator and participant in marketing communications activities 
(Constantinides \& Fountain, 2008; Godfrey et al., 2011; Hennig-Thurau et al., 2010; Kerrigan \& Graham, 2010; Weinberg \& Pehlivan, 2011). Accordingly, we propose that as customers are becoming active participants in the communication process, companies should concentrate on "soft-selling" by creating interesting and helpful digital content (Halligan \& Shah, 2009; Scott, 2010). Our results confirm that significant shifts in industrial firms' customer communications are not yet occurring.

Our data imply that general brand marketing in digital channels may not yield the desired outcomes because the message is not reaching its target audience or because the target audience is receiving the message but does not consider such general content relevant. Previous research on the utility of social media also suggests that advertising to existing customers with the aim to increase brand awareness does not significantly influence the next steps in the decision-making process (De Bruyn \& Lilien, 2008). Customer representatives contacted through social media may not actually be responsible for making the decisions. This may lead marketers to produce digital content that does not contribute significantly to any clearly defined marketing communication objective.

Some of the benefits of DMC in B2C settings are not available in industrial marketing settings because of the different norms of communication in customer relationships. For example, open or public discussion with customers in social media can threaten confidentiality and therefore breaks the norms of communication in the industrial business field. The industrial companies examined in this study were not willing to take the first steps toward more open communication because of a perceived threat of losing competitive advantage and/or customers.

Our case study only partially supports the view that DMC-and especially social media utilization-in B2B should focus on lead generation (Bodnar \& Cohen, 2012; Welling \& White, 
2006). Few industrial companies have set clear objectives for lead generation from social media, presumably because they are still new to using it. An added challenge to making social media marketing efforts cost-effective is the complex nature of the industrial purchasing process. However, DMC may provide industrial companies competitive advantage through the efficiency of internal communications, such as systematized feedback and digital exchange of information between marketing and sales functions.

Naturally, DMC itself is not a solution for existing problems in marketing communication, exemplified by issues such as a lack of integration and the need to maintain a sufficiently close relationship with existing customers. Industrial companies must carefully distinguish their marketing communication objectives, such as general brand marketing, from customer communications to choose the most suitable channel, either traditional or digital. Online and offline marketing communication efforts should work in combination to create real value for customers and stakeholders (Foster, 2005; Huntera et al., 2004).

\section{Managerial implications}

Managers should be aware of both the changing communications landscape and the habits that have already shaped the way business is conducted in many other fields, such as B2C. Managers need to support and enable effective communication to create a favorable mind-set across the whole organization; only then can DMC actions attach themselves successfully to other forms of communication.

Industrial buyers appreciate timely digital communications when gathering competing and/or complementary information, such as product specifications, supplier details, and references to support them in making decisions (Deeter-Schmelz \& Kennedy, 2002). Therefore, 
industrial companies should ensure that all necessary information is available on their websites, so that potential buyers and customers have easy access to that information. This is vital because the accessibility of information is related to the amount of risk buyers perceive in the purchasing process (Bienstock \& Royne, 2007; Smith \& Bush, 2002). In the purchasing process, the importance of personal information sources trumps that of impersonal sources in business relationship communication. At this point, the objectives of DMC turn to sales support.

Managers should also consider the various ways DMC could support personal selling, which still dominates in the industrial marketing communication mix. Examples might include digitized sales-support materials, better showcasing of products, and equipping the sales force with new mobile devices that facilitate customer relationship management. Digitization could also help trigger more systematic information exchange between sales and marketing. As a result, the marketing function could assist the sales function by offering materials that meet the customer's needs more completely. In turn, the sales function could be more aware of the need to align sales presentations to customers with the broader strategic marketing objectives of the company.

Finally, although industrial companies seem to recognize the benefits of social media in customer communication, they prefer to implement social media internally first. Internal blogs, social bookmarks, and instant messaging among employees could become more effective and interactive. In general, these companies report a willingness to learn how social media could be used and how it should be measured. Consequently, we encourage managers to proceed systematically with social media and to adopt social media platforms with care. A growing number of benchmarks available in the industrial context follow the best practices of the leading industrial firms in digitization (e.g., Ford). However, implementing social media also requires 
knowledge of the culture of communication. Not all companies value openness, as they fear handing an advantage to the competition. In addition, general presence in public social media only serves the purpose of building brand awareness among prospects and other stakeholder groups, whereas in existing business relationships, digital channels should be employed to enable even more personal and interactive communication.

\section{Limitations and further research}

Although our findings are based on extensive empirical data, they represent only six industrial companies. As such, the findings and implications are limited and cannot be generalized to other settings. We attempted to enhance the validity of the research by using multiple cases and several sources of information; to increase the construct validity of the study, we also used data analysis techniques, such as data triangulation (Denzin, 1984). As is typical in multiple case studies, some of the cases offered richer information than others. This resulted in a relatively modest analysis of some cases, because the firms did not use DMC, and marketing communications generally played a minor role in the firm's activity. In addition, the marketing function in these firms had no strategic objectives, and the data gathered from the informants did not reveal as much as that from informants in other companies.

In light of these limitations, future studies in the field are merited. Research should address the adoption and use of new digital forms of communication, such as the use of social media and social networks in industrial businesses. For example, it might be worthwhile to try to confirm whether the main function of social media really is generating leads or whether it has more to offer the soft-sell aspect of the sales process, as typified by activities such as creating awareness 
of and building the brand or enhancing communications with existing customers. Research could also examine the customer perspective to understand customer preferences for DMC. 


\section{References}

Berthon, P., Lane, N., Pitt, L., \& Watson, R. T. (1998), "The World Wide Web as an industrial marketing communication tool: models for the identification and assessment of opportunities", Journal of Marketing Management, Vol. 14, pp. 691-704.

Bienstock, C. C., \& Royne, M. B. (2007), "The differential value of information in industrial purchasing decisions: Applying an economics of information framework", International Journal of Physical Distribution and Logistics Management, Vol. 37 No. 5, pp. 389-408.

Bodnar, K., \& Cohen J. L. (2012), The B2B Social Media Book, Wiley, Hoboken, NJ.

Constantinides, E., \& Fountain, S. J. (2008), "Web 2.0: conceptual foundations and marketing issues", Journal of Direct, Data and Digital Marketing Practice, Vol. 9 No. 3, pp. 23144.

Cornelissen, J. (2004), Corporate Communication: Theory and Practice, Sage Publications, London.

Day, G., \& Bens, K. (2005), "Capitalizing on the internet opportunity", Journal of Business \& Industrial Marketing, Vol. 20 No. 4/5, pp. 160-68.

De Bruyn, A., \& Lilien, G. L. (2008), “A multi-stage model of word-of-mouth influence”, International Journal of Research in Marketing, Vol. 25 No. 3, pp. 151-63.

Deeter-Schmelz, D., \& Kennedy, K. (2002), “An exploratory study of the Internet as an industrial communication tool: examining buyers' perceptions”, Industrial Marketing Management, Vol. 31 No. 2, pp. 145-54.

Denzin, N. (1984), The Research Art, Prentice Hall, . Englewood Cliffs, NJ.

Drèze, X., \& Hussherr, F.-X. (2003), “Internet advertising: Is anybody watching?" Journal of Interactive Marketing, Vol. 17 No. 4, pp. 8-23.

Dubois, A. \& Gadde, L.-E. (2002), "Systematic combining: an abductive approach to case research", Journal of Business Research, Vol. 55, pp. 553-60.

DuFrene, D., Engelland, B., Lehman, C., \& Pearson, R. (2005), "Changes in consumer attitudes resulting from participation in a permission e-mail campaign", Journal of Current Issues and Research in Advertising, Vol. 27 No. 1, pp. 65-76.

Ford, D., Gadde, L.-E., Håkansson, H., Lundgren, A., Snehota, I., Turnbull, P., \& Wilson, D. (1998), Managing Business Relationships, Wiley, Chichester, UK.

Foster, T. (2005), "Creating digital value: at the heart of the I-E-I framework", Journal of Business \& Industrial Marketing, Vol. 20 No. 4/5, pp. 245-52.

Foster, T. (2006), "Industrial marketing communication: a (r)evolutionary journey from marketplace to market space", paper presented at the Academy of Marketing Science Conference, San Antonio, Texas, May 24-27.

Foster, T. (2006). Industrial marketing communication: A (r)evolutionary journey from marketplace to market space. Proceedings of the Academy of Marketing Science Conference, May 24-27, San Antonio, Texas. 
Gilliland, D. I., \& Johnston, W. J. (1997), “Toward a model of business-to-business marketing communications effects", Industrial Marketing Management, Vol. 26 No. 1, pp. 15-29.

Godfrey, A., Seiders, K., \& Voss, G. (2011), "Enough is enough! The fine line in executing multichannel relational communication", Journal of Marketing, Vol. 75 No. 4, pp. 94109.

Greenberg, P. (2010a), CRM at the Speed of Light: Social CRM Strategies, Tools, and Techniques for Engaging Your Customers, McGraw-Hill, New York.

Greenberg, P. (2010b), "The impact of CRM 2.0 on customer insight”, Journal of Business \& Industrial Marketing, Vol. 25 No. 6, pp. 410-419.

Halligan, B., \& Shah, D. (2009), Inbound Marketing: Get Found Using Google, Social Media, And Blogs, Wiley, Hoboken, NJ.

Hennig-Thurau, T., Malthouse, E. C., Friege, C., Gensler, S., Lobschat, L., Rangaswamy, A., \& Skiera, B. (2010), "The impact of new media on customer relationships", Journal of Service Research, Vol. 13 No. 3, pp. 311-30.

Huntera, L. M., Kasouf, C. J., Celuch, K. G., \& Curry, K. A. (2004), “A classification of business-to-business buying decisions: Risk importance and probability as a framework for e-business benefits", Industrial Marketing Management, Vol. 33 No. 2, pp. 145-54.

Jackson, D. W., Jr., Keith, J. E., \& Burdick, R. E. (1987), “The relative importance of various promotional elements in different industrial purchase situations", Journal of Advertising, Vol. 16, pp. 25-33.

Järvinen, J., Töllinen, A., Karjaluoto, H., \& Jayawardhena, C. (2012), “Digital marketing in the era of social media: use, measurement, and barriers in the B2B sector", Marketing Management Journal, Vol. 22 No. 2, pp. 102-17.

Kerrigan, F., \& Graham, G. (2010), "Interaction of regional news-media production and consumption through the social space", Journal of Marketing Management, Vol. 26 No. 3/4, pp. 302-20.

Lilien, G. L., \& Weinstein, D. (1983), “An international comparison of the determinants of industrial market expenditures", Journal of Marketing, Vol. 48 No. 1, pp. 46-53.

Manchanda, P., Dubé, J.-P., Goh, K. Y., \& Chintagunta, P. K. (2006), "The effect of banner advertising on Internet purchasing", Journal of Marketing Research, Vol. 43 No. 1, pp. 98-108.

Mangold, W. G., \& Faulds, D. J. (2009), "Social media: the new hybrid element of the promotion mix", Business Horizons, Vol. 52 No. 4, pp. 357-365.

Michaelidou, N., Siamagka, N. T., \& Christodoulides, G. (2011), "Usage, barriers and measurement of social media marketing: an exploratory investigation of small and medium B2B brands", Industrial Marketing Management, Vol. 40 No. 7, pp. 1153-59.

Miles, M. B., \& Huberman, A. M. (1994), Qualitative Data Analysis, 2nd edition, Sage Publications, Thousand Oaks, CA.

Mulhern, F. (2009), "Integrated marketing communications: from media channels to digital connectivity”, Journal of Marketing Communications, Vol. 15 No. 2, pp. 85-101. 
Parasuraman, A., \& Zinkhan, G. (2002), "Marketing to and serving customers through the internet: an overview and research agenda", Journal of the Academy of Marketing Science, Vol. 30 No. 4, pp. 286-295.

Rosenbloom, B. (2007), "Multi-channel strategy in business-to-business markets: prospects and problems", Industrial Marketing Management, Vol. 36 No. 1, pp. 4-9.

Scott, D. M. (2010), The New Rules of Marketing and PR: How to Use Social Media, Blogs, News Releases, Online Video, and Viral Marketing to Reach Buyers Directly, 2nd edition, Wiley, Hoboken, NJ.

Sharma, A. (2002), "Trends in Internet-based business-to-business marketing”, Industrial Marketing Management, Vol. 31 No. 2, pp. 77-84.

Singha, R., \& Koshyb, A. (2011), "Does a salesperson's customer orientation create value in B2B relationships? Empirical evidence from India”, Industrial Marketing Management, Vol. 40 No. 1, pp. 78-85.

Smith, R., \& Bush, A. (2002), "Using the incomplete information framework to develop service provider communication guidelines", Journal of Service Marketing, Vol. 16 No. 6, pp. 535-52.

Srinivasan, S. S., Anderson, R. E., \& Ponnavolu, K. (2002), "Customer loyalty in e-commerce: an exploration of its antecedents and consequences", Journal of Retailing, Vol. 78 No. 1, pp. 41-50.

Walters, P. G. P. (2008), "Adding value in global B2B supply chains: strategic directions and the role of the internet as a driver of competitive advantage", Industrial Marketing Management, Vol. 37 No. 1, pp. 59-68.

Weber, L. (2009), Marketing to the Social Web: How Digital Customer Communities Build Your Business, Wiley, Hoboken, NJ.

Weinberg, B. D., \& Pehlivan, E. (2011), "Social spending: managing the social media mix", Business Horizons, Vol. 54 No. 3, pp. 275-82.

Welling, R., \& White, L. (2006), "Web site performance measurement: promise and reality", Managing Service Quality, Vol. 16 No. 6, pp. 654-70.

Wertime, K., \& Fenwick, I. (2008), DigiMarketing: The Essential Guide to New Media \& Digital Marketing, Wiley, Singapore.

Wotruba, T. R. (1996), "The transformation of industrial selling: causes and consequences", Industrial Marketing Management, Vol. 25, pp. 327-38.

Wymbs, C. (2011), "Digital marketing: the time for a new 'Academic Major' has arrived", Journal of Marketing Education, Vol. 33 No. 1, pp. 93-106.

Yin, R. K. (1994), Case Study Research: Design and Methods, 2nd edition, Sage Publications, Thousand Oaks, CA. 
Table I Case companies and empirical data

\begin{tabular}{|c|c|c|c|c|}
\hline \multirow{2}{*}{$\begin{array}{l}\text { Case companies } \\
\text { (number of global personnel) }\end{array}$} & \multirow{2}{*}{$\begin{array}{l}\text { Number of business } \\
\text { areas }\end{array}$} & \multicolumn{2}{|l|}{ Empirical data } & \multirow{2}{*}{$\begin{array}{l}\text { Number of } \\
\text { meetings }\end{array}$} \\
\hline & & $\begin{array}{l}\text { Participants in } \\
\text { workshops }\end{array}$ & $\begin{array}{l}\text { Face-to-face } \\
\text { interviews }\end{array}$ & \\
\hline $\begin{array}{l}\text { A: Formed through numerous } \\
\text { acquisitions (200) }\end{array}$ & $\begin{array}{l}\text { Five different } \\
\text { businesses }\end{array}$ & $\begin{array}{l}12 \text { managers and } \\
\text { directors }\end{array}$ & 1 & 2 \\
\hline $\begin{array}{l}\text { B: Part of a larger corporation } \\
(15,000)\end{array}$ & One main business & 12 marketing staff & 1 & 2 \\
\hline C: Large corporation $(8,000)$ & One main business & $\begin{array}{l}5 \text { managers and } \\
\text { business unit } \mathrm{VP}\end{array}$ & 9 & 2 \\
\hline $\begin{array}{l}\text { D: Spin-off of a larger } \\
\text { corporation }(2,000)\end{array}$ & $\begin{array}{l}\text { One main business } \\
\text { with three diverse } \\
\text { business units }\end{array}$ & $\begin{array}{l}16 \text { managers across } \\
\text { business units }\end{array}$ & 22 & 3 \\
\hline $\begin{array}{l}\text { E: Young, small firm with few } \\
\text { customers }(200)\end{array}$ & One main business & $\begin{array}{l}\text { No workshop, small } \\
\text { marketing function }\end{array}$ & 15 & 2 \\
\hline $\begin{array}{l}\text { F: Growing firm with one core } \\
\text { product }(1,000)\end{array}$ & One main business & 15 marketing staff & 13 & 2 \\
\hline
\end{tabular}


Table II An overview of marketing communications in the case companies

\begin{tabular}{llll}
\hline $\begin{array}{l}\text { We are good at } \\
\begin{array}{l}\text { Themes } \\
\text { Tools }\end{array}\end{array}$ & First-ranked & Second-ranked & Third-ranked \\
\hline $\begin{array}{l}\text { Our weaknesses are } \\
\text { Themes }\end{array}$ & $\begin{array}{l}\text { Visual matters } \\
\text { Public relations }\end{array}$ & $\begin{array}{l}\text { Brand and image } \\
\text { Exhibitions }\end{array}$ & $\begin{array}{l}\text { Credibility } \\
\text { DMC }\end{array}$ \\
Tools & Integration (IMC) & $\begin{array}{l}\text { Internal } \\
\text { communication } \\
\text { Generating word of } \\
\text { mouth }\end{array}$ & $\begin{array}{l}\text { Strategy and } \\
\text { planning } \\
\text { Direct marketing }\end{array}$ \\
\hline $\begin{array}{l}\text { Development areas } \\
\text { Themes }\end{array}$ & Integration (IMC) & $\begin{array}{l}\text { Internal } \\
\text { communication }\end{array}$ & $\begin{array}{l}\text { Customer } \\
\text { relationship } \\
\text { management system } \\
\text { Direct marketing }\end{array}$ \\
\hline
\end{tabular}




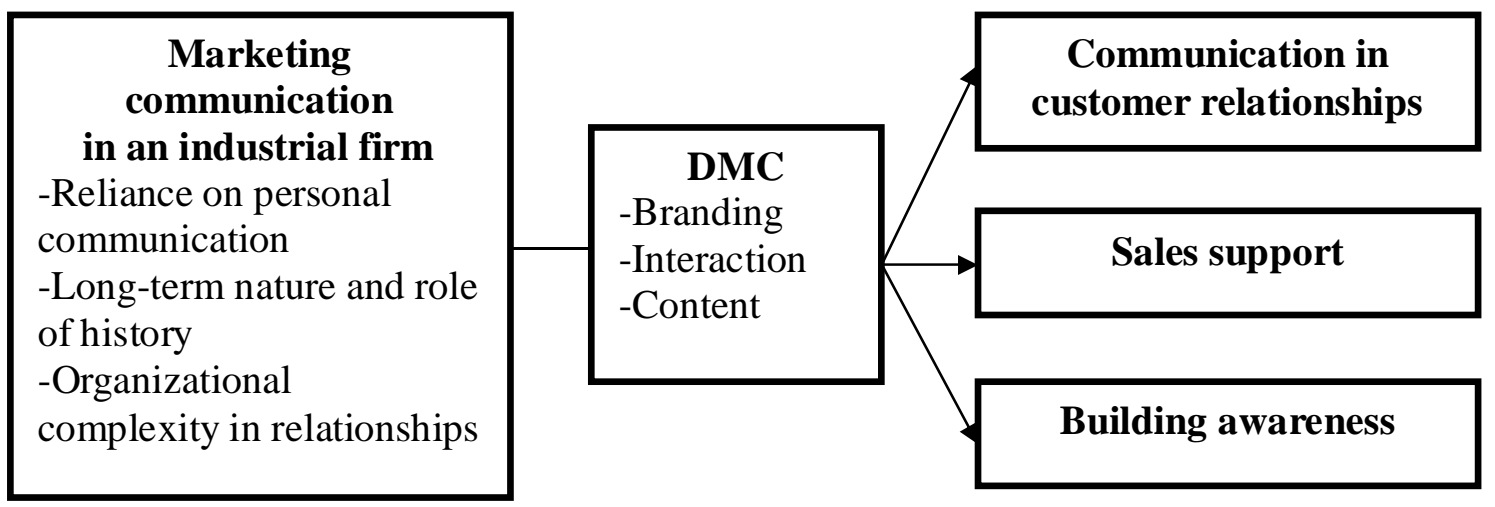

Figure 1 Use of DMC in the industrial marketing context 